\title{
DYNAMICS OF GASEOUS EMISSIONS DURING COMPOSTING OF SEWAGE SLUDGE WITH MAIZE STRAW AS A BULKING AGENT
}

\author{
Wojciech Czekała', Jacek Dach¹, Krystyna Malińska², Jacek Przybył', Magdalena Myszura³ \\ 1 Institute of Biosystems Engineering, Poznań University of Life Sciences, Wojska Polskiego 50, 60-637 Poznań, \\ Poland, e-mail: wojciech@up.poznan.pl; jdach@up.poznan.pl \\ ${ }^{2}$ Institute of Environmental Engineering, Czestochowa University of Technology, Brzeźnicka 60a, 42-200 \\ Częstochowa, Poland, e-mail: kmalinska@is.pcz.czest.pl \\ ${ }^{3}$ Institute of Soil Science and Environment Shaping, University of Life Sciences in Lublin, Leszczyńskiego 7, \\ 20-069 Lublin, Poland
}

Received: 2015.03.02 Accepted: 2015.06.02 Published: 2015.07.01

\begin{abstract}
In order to ensure proper composting of sewage sludge it is necessary to use bulking agents which will create favorable water and air conditions inside the pile and will be an additional source of carbon for the improvement of the $\mathrm{C}$ : $\mathrm{N}$ ratio of a composted mixture. However, the cereal straw widely used for composting of sewage sludge is very expensive and has a negative impact on the economic balance of the operations of a composting plant. Therefore, there is a need for novel, alternative materials that can be used as cheap and effective bulking agents for composting of sewage sludge. The aim of this study was to investigate the composting process of municipal sewage sludge and maize straw as a structural addition. The study was conducted in a specialized bioreactor for modeling aerobic or anaerobic decomposition process of organic materials. The bioreactor was equipped with 165-liter, thermally insulated chambers, controlled air flow and a system of gases and temperature analyzers. The studies have shown that composting of sewage sludge with the addition of maize straw leads to a very intense thermophilic phase resulting in strong emission of $\mathrm{CO}_{2}$. The usage of maize straw allowed to reduce the ammonia emissions and the amount of leachate. The obtained compost had favorable physicochemical and organoleptic properties, i.e. it showed neutral smell of the forest litter, good fragmentation and was not clammy.
\end{abstract}

Keywords: waste management, composting, sewage sludge, bulking agent, maize straw, gaseous emissions.

\section{INTRODUCTION}

Nowadays, one of the most pressing problems concerning protection of the environment is waste management [Dach et al., 2014]. This is related to the requirement to adapt the national law to the European Union legislation [Janczak et al., 2013a]. One of the most environmentally troublesome waste is sewage sludge that is related to living conditions of human activity [Jędrczak, 2007]. Wastewater after treatment can be discharged into a reservoir, while the sewage sludge must be subjected to additional treatment primarily oriented towards stabilization [Andrés and Walter, 2010].
This allows hygienisation of waste and reduction of the amount of emitted odor [Imhoff, 1996]. The National Waste Management Plan (2010) provides the rules and guidelines for management of sewage sludge. The main objective of this Plan is to minimize generation of sewage sludge.

However, this task is extremely difficult because the amount of sewage sludge is increasing every year, which is caused by, among others, the increase in areas with wastewater collection system, modernization of old wastewater treatment plants, construction of new ones and improvement of our life quality. Sewage sludge can be used directly on agricultural areas [Conde Suárez et al. 2004] or 
can be subjected to various disposal and recovery treatments. One of these methods for disposal of sewage sludge is composting [Haug, 1993; WolnaMaruwka and Czekała, 2007]. This process allows oxygen stabilization of sewage sludge [Czekała et al., 2012; Sidełko et al., 2011] and conversion into a mature compost and an environmentally safe product [Singha and Agrawal, 2008].

From the environmental point of view, the most unfavorable method of sewage sludge management is landfilling which was predominant in Poland. However, since January 2013 landfilling of sewage sludge has been banned. Therefore, the existing approaches towards sewage sludge utilization require proper adjustment [Malińska and ZabochnickaŚwiątek, 2013]. Taking into account these unfavorable proportions in waste management we are obliged to look for alternative options in order to reduce the quantities of generated sewage sludge (Figure 1) [Siebielska and Janowska, 2011]. The definition provided in the section II, chapter 2, Article 18 of the Act on Waste [Act on Waste, 2012] defines organic recycling as aerobic treatment, including composting, or anaerobic treatment. This means that waste is decomposed under controlled conditions with usage of micro-organisms and as a result organic matter or methane is formed.

The national (and the European Union) legislation points out that the basic method of waste disposal (except from the limitation of the amount of generated waste) should be recovery, and then disposal. Composting which is referred to as R3 recovery method - from the legal point of view - should be a preferred method of sewage sludge management. And for this reason, the National
Program for Municipal Wastewater Treatment has assumed that agricultural use of composted sewage sludge should be a preferred direction of sewage sludge usage [Janosz-Rajczyk, 2004]. Properly conducted composting of sewage sludge is desirable not only because it improves hygienic conditions but also because it allows to reduce greenhouse gases emissions [Bourne et al., 2012] and odors. This issue is of great importance because the waste, including sewage sludge, is one of the emission sources of methane, ammonia or hydrogen sulfide into the atmosphere.

One of the biggest problems associated with composting of sewage sludge is unfavorable $\mathrm{C}: \mathrm{N}$ ratio, resulting from nitrogen surplus. This is undesirable because the excess of nitrogen can escape to the atmosphere in a form of ammonia. Considering organic carbon deficiency in the waste, it becomes necessary to amend the mixture with bulking agents, such as straw, bark, woodchips [Melero et al., 2007; Malińska \& Zabochnicka-Świątek, 2013] or materials such as biochar, zeolites or diatomite which can reduce ammonia emissions during the process [Malińska et al., 2004; Zabochnicka-Świątek and Malińska, 2010; Malińska et al., 2014].

However, due to high demand of renewable energy sector [Lewicki et al., 2013], both cereal straw and sawdust are available at high prices, generally exceeding in case of straw level of 35 Euro/t. Therefore, there is a need for alternative biomass that can be used as structural support for composting of sewage sludge. Maize straw can be used as a bulking agent for composting of sewage sludge. The obtained compost will not only accommodate waste

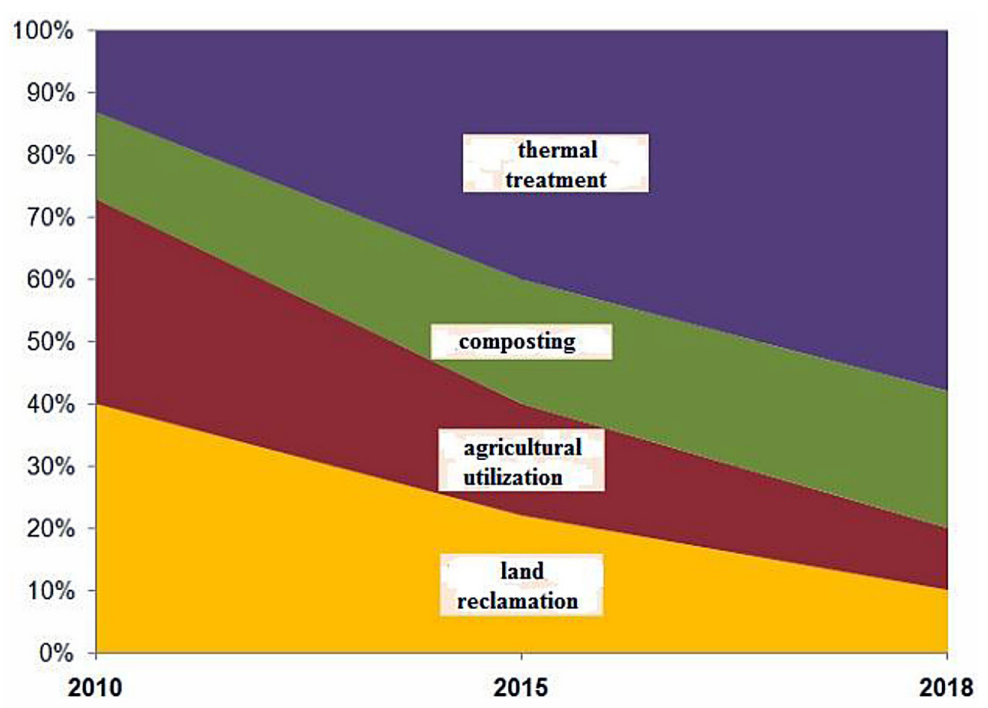

Figure 1. Expected changes in the structure of municipal sewage sludge disposal in Poland until 2018 [The 2010 National Waste Management Plan] 
used in its production but also provide valuable fertilizer [Cuevas et al., 2003; Boruszko, 2011].

The main aim of this study was to investigate the potential of maize straw as a bulking agent in composting of sewage sludge. The scope of the presented research included composting of sewage sludge mixed with maize straw as a bulking agent and evaluation of the effect of maize straw on gaseous emissions and characteristics of the obtained compost.

\section{MATERIALS AND METHODS}

Sewage sludge used in the presented research was sampled from the municipal wastewater treatment plant in Szamotuły, Poland (79\% d.m) and maize straw (19\% d.m) was harvested from a local farm near Trzcianka, Poland. The ratio of maize straw in the composting mixture was determined based on dry matter and $\mathrm{C}: \mathrm{N}$ ratio the weight load (the chamber No. $1-55 \%$ content of sewage sludge and $45 \%$ of maize straw and the chamber No. $2-45 \%$ content of sewage sludge and $55 \%$ of maize straw).

This study was conducted at the Institute of Biosystems Engineering (Poznań University of Life Sciences, PULS, Poland). The 2-chamber isolated bioreactor with the chamber volume of $165 \mathrm{dm}^{3}$ was used for the experiments (Figure 2) [Dach, 2005]. To maintain proper thermal insulation and regulation of the air flow into the investigated mixture, the bioreactor allows accurate representation of the changes occurring in anaerobically stored or composted material, including the changes of physical, chemical and microbiological parameters as well as emitted gases and energy [Czekała et al., 2006; Wolna-Maruwka, 2006]. This system enables to conduct the model research without the influence of weather conditions which can affect the results of field studies [Janosz-Rajczyk, 2004; Janczak et al., 2013b]. The temperature of the mixtures below $30^{\circ} \mathrm{C}$ was recognized as the end of the experiment.

\section{RESULTS}

The obtained results have shown that the bioreactors fully reflected the decomposition processes occurring in composted materials. It was confirmed by the achievement of high temperatures typical for intense thermophilic phase which occurs during composting process in the real scale [Dach et al., 2003; Niżewski et al., 2006].

\section{Temperature changes}

On the basis of temperature changes during the composting process, it was possible to distinguish three phases [Niżewski et al., 2006]. The most important for composting process is the $2^{\text {nd }}$ phase, i.e. thermophilic phase [Piotrowska-Cyplik et al., 2013]. During this phase the temperature growth allowing the stabilization of the compost in terms of sanitary requirements was observed [Sidełko et al., 2011]. For both mixtures, the maximum tem-

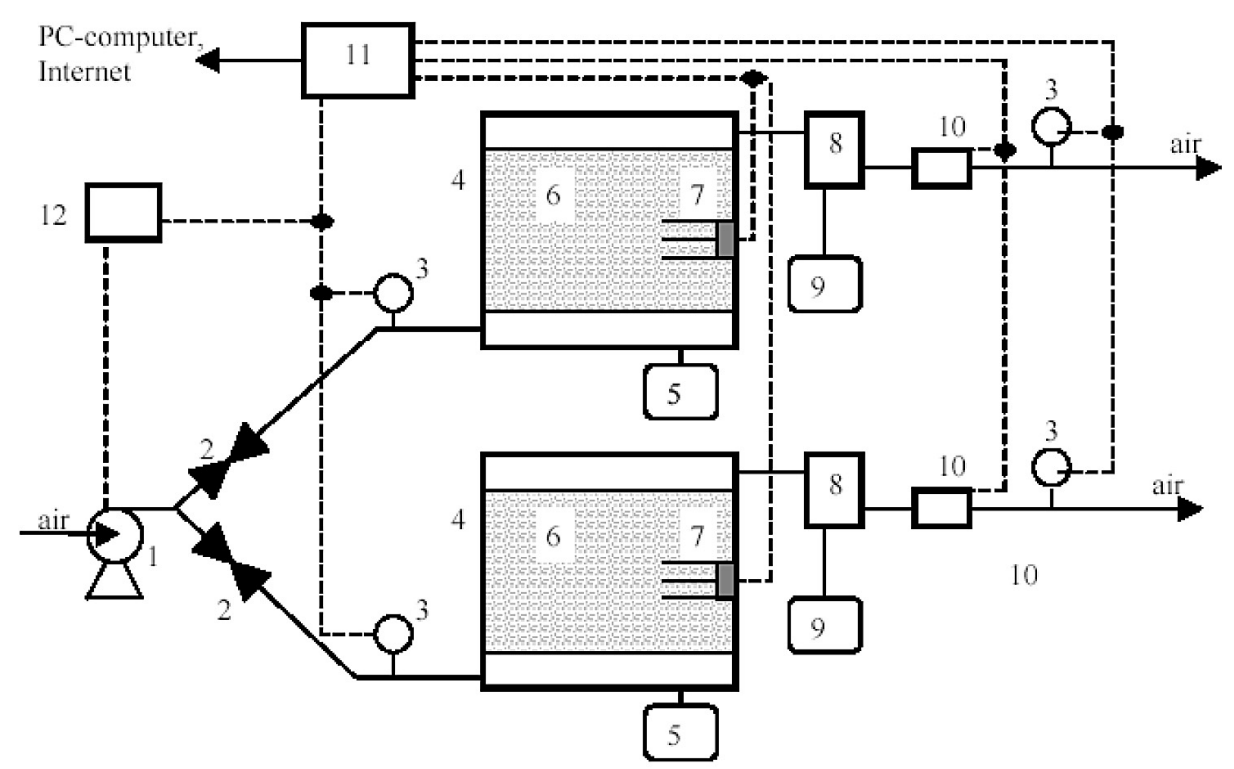

Figure 2. Schematic diagram of the 2-chamber bioreactor: 1. Pump, 2. Flow regulator, 3. Flow meter, 4. Insulated chamber, 5. Drained liquids container, 6. Composted mass, 7. Sensors set, 8. Air cooling system, 9. Condensates container, 10. Set-up of gases analysis $\left(\mathrm{NH}_{3}, \mathrm{O}_{2} / \mathrm{CO}_{2}, \mathrm{CH}_{4}, \mathrm{H}_{2} \mathrm{~S}\right), 11$. 32-channel recorder, 12. Air pomp steering system 
peratures obtained in the bioreactors reached the level of $70{ }^{\circ} \mathrm{C}$. This confirmed the occurrence of thermophilic phase and therefore the proper run of composting process [Wolna-Maruwka \& Dach, 2009]. After reaching the maximum temperature on the $3-4^{\text {th }}$ day of the experiment a gradual decrease of temperature was observed (even though the additional mixing of the investigated mixture) which resulted in maturity phase after 38 days [Figure 3].

\section{The dynamics of changes in the concentration of oxygen, carbon dioxide and hydrogen sulfide}

One of the most important parameters indicative for the proper run of composting process is constant oxygen supply to the pile. This gas is necessary for decomposition of organic matter as a result of intense development of aerobic micro-organisms [Wolna-Maruwka, 2012]. In both chambers the initial oxygen concentration reached $20.7 \%$, which was identical with its content in the atmospheric air. Along with the duration of the experiment a decrease of oxygen amount in the bioreactor chambers was observed, while the percentage of $\mathrm{CO}_{2}$ was increasing (Figures 4 and 5).

The growth of $\mathrm{CO}_{2}$ content in exhaust gas indicated the correct process run and was caused by intense decomposition of biomass and sewage sludge, which were the substrates enriched in carbon. Since the $25^{\text {th }}$ day, in comparison to the prior days, a de-

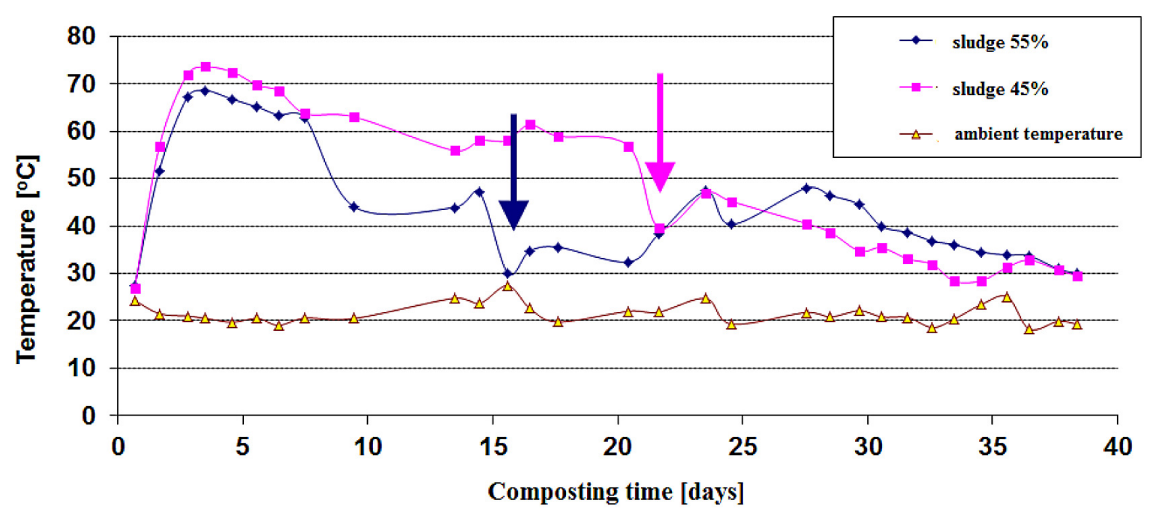

Figure 3. Temperature changes of composted mixtures and environment (vertical arrows indicate the $2^{\text {nd }}$ mixing of composted materials)

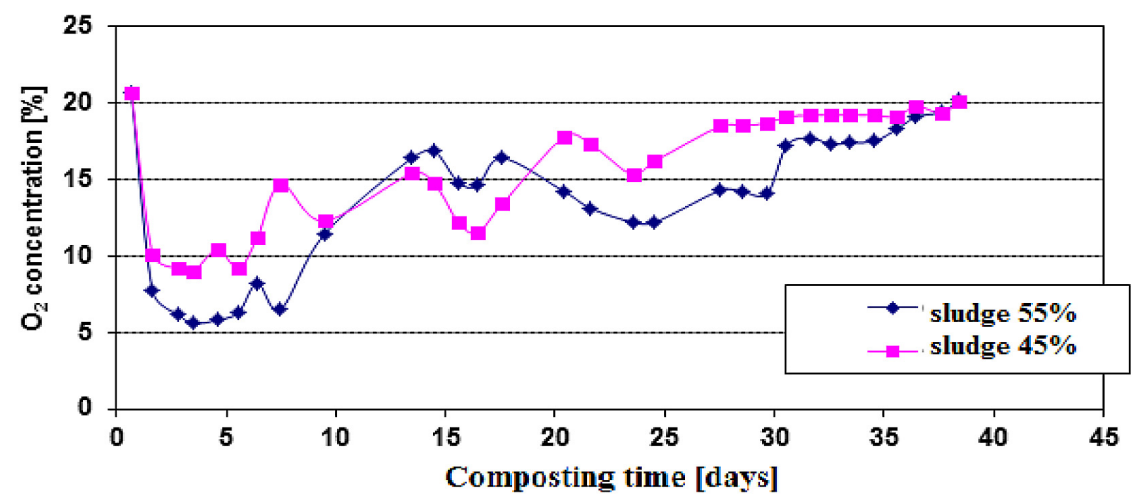

Figure 4. Changes of oxygen content in the exhaust air

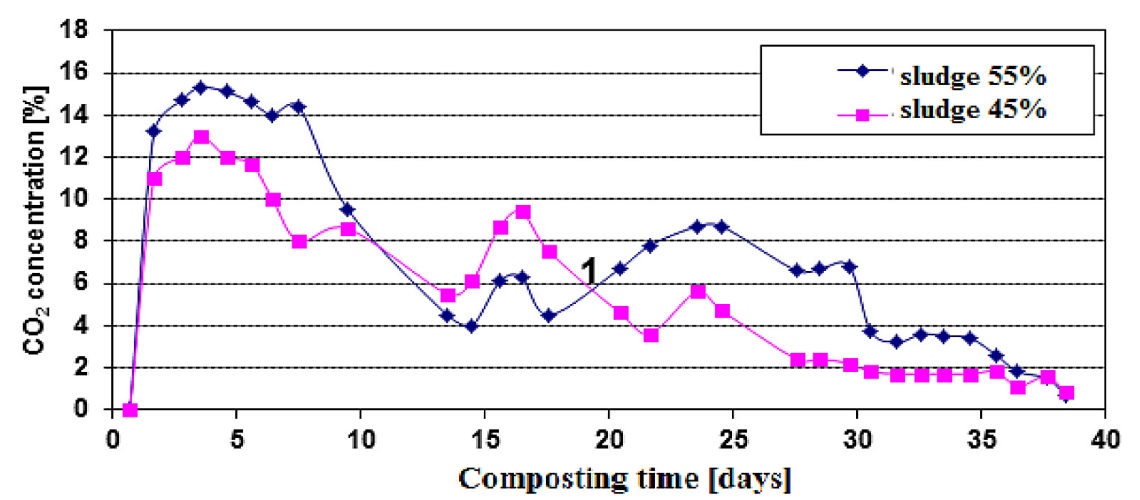

Figure 5. Changes of carbon dioxide content in the exhaust air 
crease of $\mathrm{CO}_{2}$ emission was observed with simultaneous increase of oxygen share. Achieving the state with the oxygen content at the level of $20 \%$ and loss of carbon dioxide emission after $30^{\text {th }}$ day confirmed the stabilization of the composted mixtures and expiration of intense biochemical changes characteristic for thermophilic phase.

During the experiment in both chambers of the bioreactor the hydrogen sulfide (gas of a specific unpleasant odor) was determined (Figure 6).

The highest emissions of this gas occurred during the first 5 days of the experiment and this was caused by rapid decomposition of the compounds containing the protein. The maximum concentration of $\mathrm{H}_{2} \mathrm{~S}$ amounted 703 ppm in case of the mixture with $55 \%$ of sewage sludge and 481 ppm for mixture containing $45 \%$ of sewage sludge. Along with the experiment duration the amount of emitted hydrogen sulfide decreased to immeasurable values which eventaully resulted in the neutral odor of the compost.

\section{The dynamics of changes in fresh mass, dry matter, $\mathrm{pH}$ and compost volume}

One of the characteristics confirming proper course of the composting process are the losses of fresh and dry matter of the mixture, along with the process duration. In both chambers, the observed changes indicated that the process was run correctly. The mass of the mixture with $55 \%$ of sewage sludge decreased by $41 \%$ and in case of the mixture containing $45 \%$ of sewage sludge it decreased by $44 \%$ (Figure 7 ).

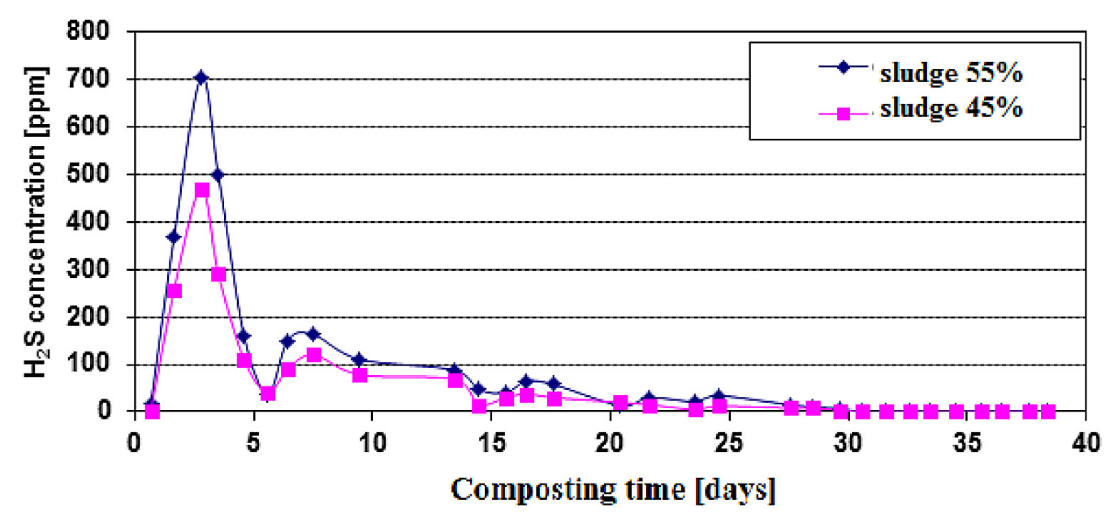

Figure 6. Changes of hydrogen sulfur content in the exhaust air

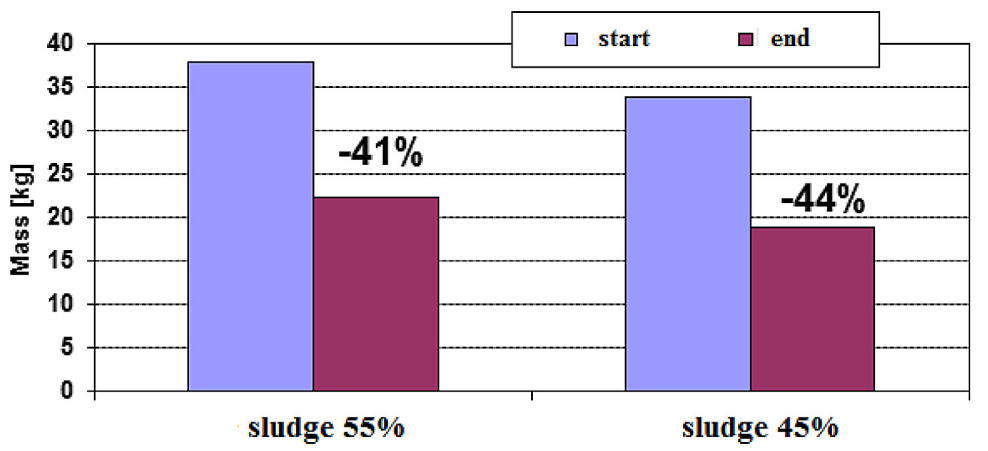

Figure 7. Comparison of the initial and final mass of composted mixtures (fresh matter)

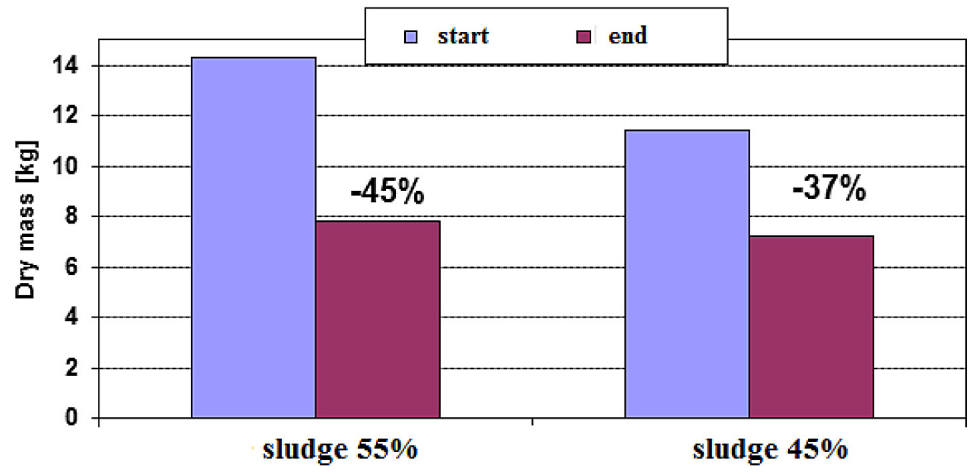

Figure 8. Comparison of the initial and final mass of composted mixtures (dry matter) 


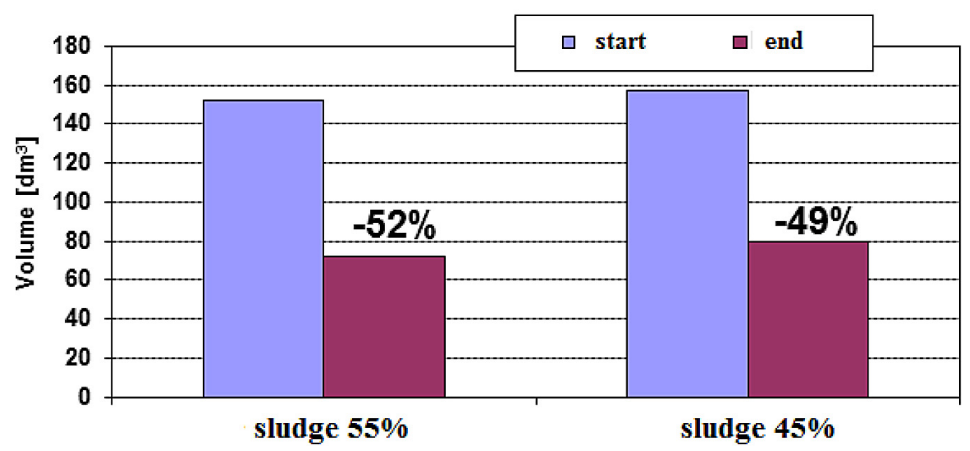

Figure 9. Comparison of the initial and final volume of composted mixtures

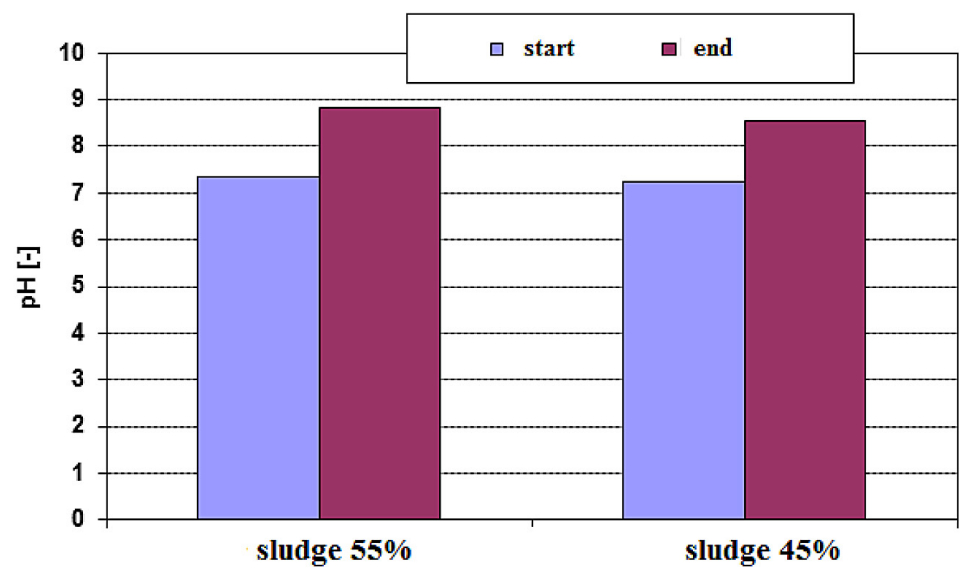

Figure 10. Comparison of the initial and final $\mathrm{pH}$ level of composted mixtures

Along with the decrease of fresh matter a loss of dry matter was observed. In case of compost containing $55 \%$ of sewage sludge in the initial mixture it amounted to $45 \%$. Slightly lower loss amounting to $37 \%$ occurred in the second composted mixture (Figure 8).

With the decrease in mass, the volume of composted mixtures also diminished. This loss was mainly caused by straw decomposition (as a structural material) and water evaporation in the thermophilic phase of the process. Slightly higher decrease of the volume amounting to $52 \%$ occurred in the chamber containing $55 \%$ of sewage sludge (Figure 9 ).

A very important parameter confirming the proper composting course is $\mathrm{pH}$ change in the mixtures. $\mathrm{pH}$ is the key parameter for survival and activity of the respective groups of organisms. The alkalinity increase was noted in both tested mixtures (Figure 10).

\section{CONCLUSIONS}

Based on the obtained results the following conclusions have been formulated:

1. Maize straw as a material rich in carbon is a sufficient amendment to sewage sludge composting and allows a suitable $\mathrm{C}: \mathrm{N}$ ratio.
2. Maize straw has fulfilled its role as a bulking agent providing an adequate porosity in the compost. Free spaces in the mixture enabled proper oxygen flow, thereby ensuring occurrence of the thermophilic phase.

3. The dependencies between the amount of $\mathrm{CO}_{2}$ and $\mathrm{O}_{2}$ in the studied composts prove the proper course of anaerobic digestion. The increase in $\mathrm{CO}_{2}$ content, identical with the decrease of $\mathrm{O}_{2}$ concentration in the bioreactor chambers proved the distribution intensity of composted material.

\section{Acknowledgements}

The studies were performed within the research project "Technology of harvesting and storage of maize straw as an energy biomass and structural substrate for composting process" (No.: N N313 270938).

\section{REFERENCES}

1. Andrés E.F., Tenorio J.L., Walter I., 2010. Biomass production and nutrient concentration of kenaf grown on sewage sludge-amended soil. Span. J. Agric. Res. 8(2). 472-480.

2. Boruszko D., 2011. Badania i ocena wartości nawozowej kompostów i wermikompostów. Rocz. Ochr. Środ. 89 (13), 1417-1428. 
3. Bourne M., Childs J., Philippidis G., Feijoo M., 2012. Controlling greenhouse gas emissions in Spain: What are the costs for agricultural sectors? Span. J. Agric. Res. 10 (3), 567-582.

4. Conde Suárez P., Seoane S., López Mosquera E., Solla-Gullón F., Merino A., 2004. Dairy industry sewage sludge as a fertilizer for an acid soil: a laboratory experiment with Lolium multiflorum L. Span. J. Agric. Res. 2 (3), 419-427.

5. Cuevas G., Martinez F., Walter I., 2003. Field-grown maize (Zea may L.) with composted sewage sludge. Effects on soil and grain quality. Span. J. Agric. Res. 1 (3), 111-119.

6. Czekała J., Dach J., Wolna-Maruwka A., 2006. Wykorzystanie bioreaktora do badań modelowych kompostowania osadu ściekowego. WodaŚrodowisko-Obszary Wiejskie, 6, z. 2(18), 29-40.

7. Czekała W., Pilarski K., Dach J., Janczak D., Szymańska M., 2012. Analiza możliwości zagospodarowania pofermentu z biogazowni. TROL 4, 13-15.

8. Dach J., 2005. Polish experience with ammonia emission abatement for straw-based manure. In: Emissions from European agriculture. Wageningen Academic Publishers, Holland, 295-303.

9. Dach J., Jędruś J., Adamski M., Kowalik I., Zbytek Z., 2003. Bioreaktor do badań procesów rozkładu materiałów organicznych. J. Res. Appl. Agric. Engin. 48(4), 74-77.

10. Dach J., Boniecki P., Przybył J., Janczak D., Lewicki A., Czekała W., Witaszek K., Rodríguez Carmona P. C., Cieślik M. 2014. Energetic efficiency analysis of the agricultural biogas plant in $250 \mathrm{kWe}$ experimental installation. Energy 69, 34-38.

11. Haug R.T., 1993. The Practical Handbook of Compost Engineering, Lewis Publishers. Boca Raton, Ann Arbor, London, Tokyo.

12. Imhoff K., 1996. Kanalizacja miast i oczyszczanie ścieków, Projprzem-EKO, Poland.

13. Janosz-Rajczyk M. (red.), 2004. Komunalne osady ściekowe - podział, kierunki zastosowań oraz technologie przetwarzania, odzysku i unieszkodliwiania. Raport dla Ministra Środowiska, Inst. Inżyn. Środ.

14. Janczak D., Lewicki P., Mazur R., Boniecki P., Dach J., Przybył J., Pawlak M., Pilarski K., Czekała W. 2013a. The selected examples of the application of computer image analysis in the assessment of environmental quality. Proc. SPIE. 8878, Fifth International Conference on Digital Image Processing (ICDIP 2013), July 19, 2013. Doi: 10.1117/12.2031069.

15. Janczak D., Marciniak M., Lewicki A., Czekała W., Witaszek K., Rodríguez Carmona P. C., Cieślik M., Dach J. 2013b. Bioreactor Internet System for Experimental Data Monitoring and Measurement. Procedia Technology 8, 209-214.

16. Jędrczak A, 2007. Biologiczne przetwarzanie odpadów. Wydawnictwo Naukowe PWN, Poland.

17. The 2010 National Waste Management Plan. Ministry of Environmental, Poland.

18. Lewicki A., Dach J., Janczak D., Czekała W. 2013.
The experimental macro photoreactor for microalgae production. Procedia Technology 8, 622-627.

19. Malińska K., Malina G., Krajewski D., Rećko T., Veeken A., Hamelers B. 2004. The role of structure in composting of sewage sludge and diatomite. In: Europ. Symp. on Environ. Biotechnol. 679-682.

20. Malińska K., Zabochnicka-Świątek M., 2013. Selection of bulking agents for composting of sewage sludge. Environ. Prot. Eng. 39(2), 89-101.

21. Malińska K., Zabochnicka-Świątek M., Dach J., 2014. Effects of biochar amendment on ammonia emission during composting of sewage sludge. Ecol. Engin. 71, 474-478.

22. Melero S., Madejón E., Herencia J.F., Ruiz J.C., 2007. Biochemical properties of two different textured soils (loam and clay) after the addition of two different composts during conversion to organic farming. Spanish J. of Agric. Res. 5(4), 593-604.

23. Niżewski P., Dach J., Jędruś A., 2006. Zagospodarowanie zużytego podłoża z pieczarkarni metodą kompostowania. J. Res. Appl. Agric Engin. 51(1), 24-27.

24. Piotrowska-Cyplik A., Chrzanowski Ł., Cyplik P., Dach J., Olejnik A., Staninska J., Czarny J., Lewicki A., Marecik R., Powierska-Czarny J., 2013. Composting of oiled bleaching earth: Fatty acids degradation, phytotoxicity and mutagenicity changes. Int. Biodeter. Biodegr.78, 49-57.

25. Sidełko R., Seweryn K., Walendzik B., 2011. Optymalizacja procesu kompostowania w warunkach rzeczywistych. Roczn Ochr Sr 41(13): 681-692.

26. Siebielska I., Janowska B., 2011. Porównanie zawartości wybranych metali ciężkich w próbkach kompostów. Roczn. Ochr. Sr. 49(13), 815-830.

27. Singha R.P., Agrawal M., 2008.Potential benefits and risks of land application of sewage sludge. Waste Manage. 28 (2), 347-358.

28. Act on Waste (Dz.U. 2013 nr 0 poz. 21).

29. Wolna-Maruwka A., Czekała J., Dach J., 2005. Dynamika zmian drobnoustrojów w osadzie ściekowym kompostowanym ze słomą. ZPPNR 506, 531-540.

30. Wolna-Maruwka A., Czekała J., 2007. Dynamics of changes in the number of selected microorganism groups in sewage sludge and in manure subject to composting process and in the soil enriched with composts. Arch. Environ. Prot. 33 (4), 53-66.

31. Wolna-Maruwka A., Dach J., 2009. Effect of Type and Proportion of Different Structure-Creating Additions on the Inactivation Rate of Pathogenic Bacteria in Sewage Sludge Composting in a Cybernetic Bioreactor. Arch. Environ. Prot. 35(3), 87-100.

32. Wolna-Maruwka A., Schroeter-Zakrzewska A., Dach J., 2012. Analysis of the growth and metabolic activity of microorganisms in substrates prepared on the base of sewage sludges and their impact on growth and flowering of garden verbena. Fresen Environ Bull 21(2), 325-336.

33. Zabochnicka-Świątek M., Malińska K., 2010. Removal of ammonia by clinoptilolite. Global Nest. J. $10(2), 256-261$. 